\title{
Coupling WRF and NRCS-CN Models for Flood Forecasting in Paraíba do Meio River Basin in Alagoas, Brazil
}

\author{
André Gonçalo dos Santos ${ }^{1}$ (D), José Nilson Beserra Campos ${ }^{1}$ (D), \\ Rosiberto Salustiano Silva Junior ${ }^{2}$ \\ ${ }^{1}$ Departamento de Engenharia Hidráulica e Ambiental, Centro de Tecnologia, Universidade \\ Federal do Ceará, Fortaleza, CE, Brasil. \\ ${ }^{2}$ Instituto de Ciências Atmosféricas, Universidade Federal de Alagoas, Maceió, AL, Brasil.
}

Received: 24 January 2018 - Accepted: 27 May 2019

\begin{abstract}
Coupling the WRF and NRCS-CN models was assessed as a tool for a flood forecast system. The models were applied to the Paraíba do Meio River basin, located in Alagoas, Brazil. FNL (Final Analysis GFS) data provided by the Global Forecast System model were used as initial conditions for WRF. Precipitations and observed discharges were collected in data collection platforms. Nine microphysics configurations were used to optimize WRF forecast. For hydrological, the automatic calibrations, available in HMS was used to get the optimum CN model parameters. Optimized precipitations Model performance was assessed with the indicators: bias, root-mean-square error, Pearson's linear correlation coefficient, Nash-Sutcliffe coefficient, Heidke skill score, hit rate and false alarm rate. WRF's predictive ability for the optimum configuration was satisfactory. The NRCS-CN yielded good results. The predictive ability of the hydrological model was ranked between satisfactory and acceptable. In a flood forecasting step, the coupled model yielded NashSutcliffe of 0.749 and 0.572 for Atalaia and Viçosa basins. Overall, the method showed potential for the development of a flood alert system.
\end{abstract}

Keywords: WRF model, NRCS-CN model, short-term rainfall forecasting, flood forecast.

\section{Acoplamento dos modelos WRF e NRCS-CN para previsão de cheias na bacia do rio Paraíba do Meio em Alagoas, Brasil}

\begin{abstract}
Resumo
O acoplamento dos modelos WRF e NRCS-CN foram avaliados como ferramentas para um sistema de previsão de cheias. Os modelos foram aplicados na bacia hidrográfica do rio Paraíba do Meio, localizada em Alagoas, Brasil. FNL (Final Análises GFS) dados obtidos do Sistema de Previsão Global foram utilizados como condições iniciais para o WRF. Precipitações e vazões observadas foram coletadas das plataformas de observação de dados. Nove configurações de microfísica foram usadas para otimizar as previsões do WRF. Para o modelo hidrológico, foram utilizadas calibrações automáticas disponíveis no HMS. Foram otimizados os parâmetros do modelo NRCS-CN. O desempenho dos modelos foi avaliado com os indicadores: viés, mínimo erro quadrático, coeficiente de correlação linear de Pearson, coeficiente de Nash-Sutcliffe, Heidke skill score, acertos e alarmes falsos. A habilidade de previsão do WRF para a configuração ótima foi considerada satisfatória. O modelo NRCS-CN gerou bons resultados de cheias. A habilidade preditiva do modelo hidrológico variou de satisfatória a aceitável. Na etapa de previsão de cheias, o modelo acoplado gerou coeficientes de Nash-Sutcliffe de 0.749 e 0.572 para as bacias Atalaia e Viçosa. Em seu todo, o modelo acoplado apresentou um bom potencial para desenvolvimento de sistemas de alerta.
\end{abstract}

Palavras-chave: modelo WRF, modelo CN-NCRS, previsão de cheias, previsão de chuvas de curto tempo.

Autor de correspondência: André Gonçalo dos Santos, andregs9@yahoo.com.br. 


\section{Introduction}

Many studies have been done coupling meteorological to hydrologic models for improving decisions on water resources management and planning. Thom et al. (2017) used gridded rainfall products in SWAT model, to estimate discharges in Srepok River Catchment in Vietnam. Givati et al. (2012) coupled the WRF model to the Hydrological Model of Karst Environment (HYMKE) for predicting streamflow operationally for the high Jordan River Basin. Shrestha et al. (2014) used data from downscaling from of the HadCM3 global circulation model as input for the hydrological model in HEC-HMS to study the impacts of climate change in Kulekhani Hydropower Project in Nepal. Alves et al. (2012) coupled a regional atmospheric spectral model (RSM) to SMAP hydrological model for defining reservoir release rules in semiarid region of Brazil.

The coupling of forecasting precipitation models with hydrological models with a short-term horizon is fundamental for developing flood alert systems in urban and rural areas. The prediction of floods and the issuance of warnings to populations can save human and animal lives and reduce damage. Many studies have focused on the improvement of coupled models and their assessments (Chen et al., 2011; Linares-Rodriguez et al., 2015; Yang et al., 2015; Shahid et al., 2017; Ratna et al., 2017).

The coupling of climate and hydrological models can be unidirectional (off-line) or bidirectional (online). In unidirectional coupling, meteorological data predicted using an atmospheric model and rainfall and evapotranspiration are used as input data in a hydrological model. This coupling offers improved flexibility and operational autonomy. In bidirectional coupling, there is an exchange of data between meteorological and atmospheric models, resulting in an integrated model called a hydrometeorological model. The incompatibilities of time and spatial scales are considered the major problems in bidirectional coupling. Nevertheless, bidirectional coupling has great potential for flood forecasting (Yu et al., 1999).

This method was applied by Meller et al. (2014) for flood forecasting in the Paraopeba River basin, located in the state of Minas Gerais, using the Model for Large Basins of the Hydraulics Research Institute - MGB-IPH) and rainfall forecasts developed at the University of São Paulo. The results showed promise for identifying and predicting floods. Calvetti and Pereira Filho (2014) applied the WRF model coupled to TopModel, in hourly time step, for streamflow prediction in Iguaçu river basin in southern Brazil. The authors found better results using more complex microphysics schemes.

In this paper, the coupling of the WRF atmospheric model with the NRCS-CN hydrological model using the software HMS (NRCS: Natural Resources Conservation Service; CN: Curve Number; HMS: Hydrological Model
Systems) was analyzed for developing a flood forecasting and alert system for the Paraíba do Meio River. To improve our knowledge of atmospheric models, nine microphysics and convection configurations were assessed for the WRF model. In addition to the coupling of the atmospheric and hydrological models, this study is innovative in that it yielded an optimal microphysics and convection configuration for the WRF coupled with optimal NRCS parameters in the coast of Northeastern Brazil. Unidirectional coupling was adopted due to its potential for providing flowrate forecasts and its easy model coupling.

\section{Study Area}

The hydrographic basin of the Paraíba do Meio River (HBPM) is located between latitudes $8^{\circ} 44^{\prime}$ and $9^{\circ} 44^{\prime}$ south and longitudes $36^{\circ} 48^{\prime}$ and $35^{\circ} 52^{\prime}$ west. It measures $3,148.5 \mathrm{~km} 2$, of which $1,964.66 \mathrm{~km} 2$ is in the state of Alagoas and $1,183.8 \mathrm{~km}^{2}$ in the state of Pernambuco (Fig. 1).

The HBPM is underlain by two geological domains. Crystalline soils prevail in the upstream portion, and sedimentary soils prevail in the downstream portion. The elevation of the basin ranges from $1,024 \mathrm{~m}$ at the riverhead to $1.0 \mathrm{~m}$ at the river's mouth. The relief ranges from rugged to undulatory in the upper valley, in the region of the Borborema Plateau. The lower valley is characterized by smooth relief in the region of the coastal tablelands and in the fluvial-lagoonal plains.

The head of the Paraíba do Meio River is located in the city of Bom Conselho, state of Pernambuco, at an elevation of $800 \mathrm{~m}$. The river empties into the Mundaú-Manguaba estuarine lagoon complex in the city of Pilar, on the coast of the state of Alagoas. The river generally flows southeast, is $172 \mathrm{~km}$ long, and has a perennial fluvial regime.

The HBPM is located in the eastern part of northeastern Brazil. In this region, $60 \%$ of the rainfall occurs during the four months of April to July. The mean annual rainfall ranges from $1,300 \mathrm{~mm}$ at the coast to $700 \mathrm{~mm}$ at the riverhead (Rao et al., 1993; Vitorino et al., 1997).

The following synoptic systems act in the region: cold fronts and their remnants (Kousky, 1979), waves from the east (Yamazaki and Rao, 1977), VCANs (Gan and Kousky, 1986), CCMs (Alves, 2001) and wavelike disturbances of the trade winds. The number of rainy days ranges from 70 to 120 (Silva et al., 2012).

\section{Data and Methods}

\subsection{Data}

Two series of rainfall and flowrate data, collected at data collection platforms (DCPs) (Table 1), were used. The rainfall series spanned a 120-hour period from July 27 


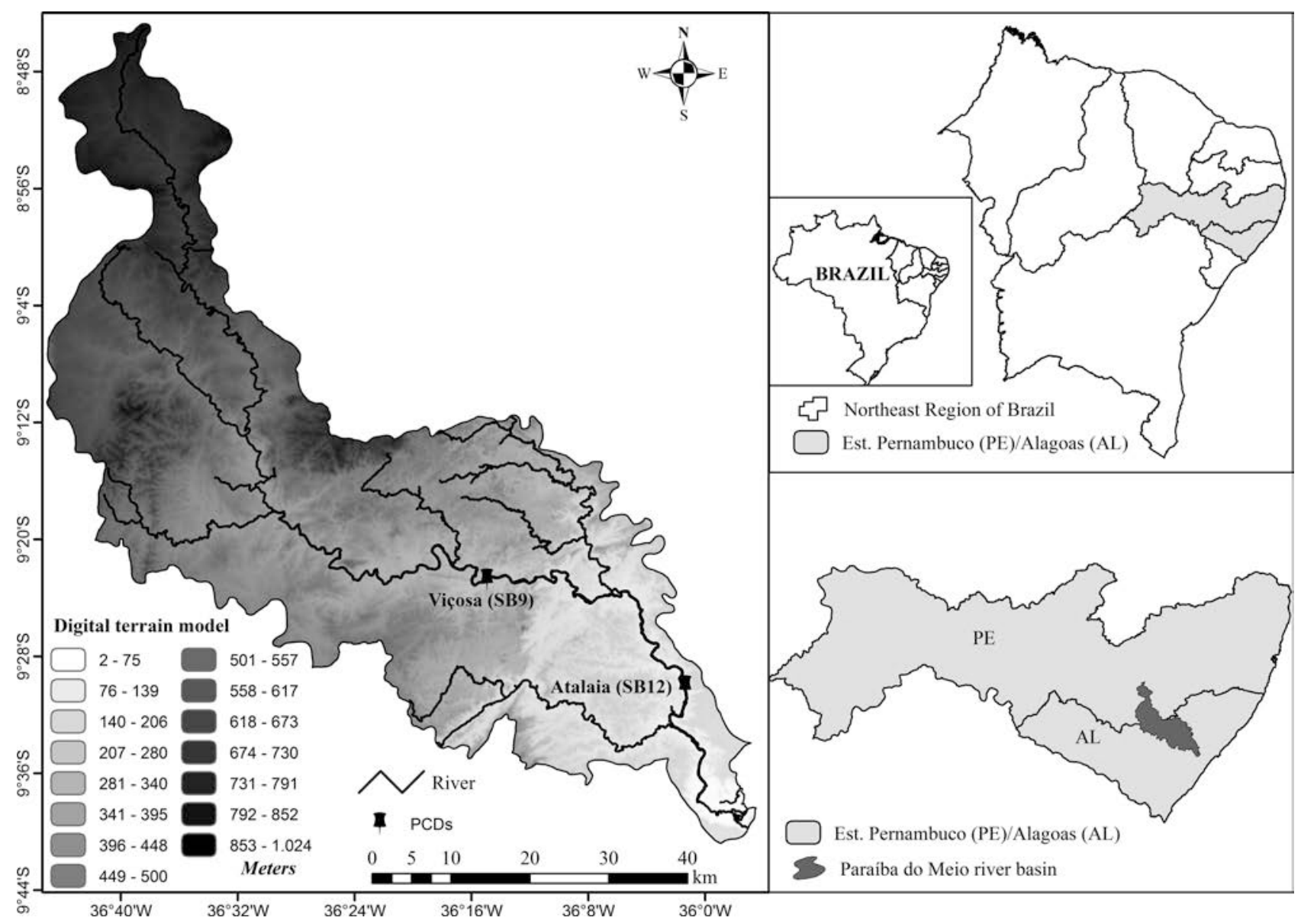

Figura 1 - Location of the Paraíba do Meio River basin, in Alagoas, Brazil.

to 31,2011 , and the series used in the validation phase spanned $192 \mathrm{~h}$ from June 1 to 8, 2013. The flowrate series used in the calibration and validation of the hydrological model contained 120 records (July 1 to 5, 2013) and 192 records (July 9 to 16, 2013), respectively. For the hydrological modelling, the rainfall and flowrate data were stored in the data storage system (DSS) of the Hydrologic Engineering Center (HEC). The spatial distribution in the basin was obtained using the Thiessen polygon.

As initial boundary conditions for the WRF, data in a $1.0^{\circ} \times 1.0^{\circ}$ grid were operationally prepared every six hours (12 a.m., 6 a.m., 12 p.m. and 6 p.m. Universal Coordinated Time (UTC). The data were provided by the National Center for Environmental Prediction (NCEP) of the Final Operational Global Analysis (FNL). The FNL data were generated using the same model used by the NCEP in the Global Forecast System (GFS) (Almeida and Marton 2014).

\subsection{WRF atmospheric model}

The WRF is a cutting-edge numerical atmospheric model developed by several research centers and government agencies in the United States, including the National Center for Atmospheric Research (NCAR), Mesoscale and Microscale Meteorology Division of the National Oceanic and Atmospheric Administration (NOAA), the National Center for Environmental Prediction (NCEP), and the

Table 1 - DCPs used for the calibration and validation of the WRF and SCS/HMS models.

\begin{tabular}{|c|c|c|c|c|}
\hline Station - DCPs & Code & Station type & Latitude & Longitude \\
\hline \multirow[t]{2}{*}{ Viçosa/AL (SB9) } & 936119 & Rainfall & $-922 ’ 45.12 ”$ & $-3614^{\prime} 57.12^{\prime \prime}$ \\
\hline & 39710000 & Flowrate & & \\
\hline \multirow[t]{2}{*}{ Atalaia/AL (SB12) } & 936110 & Rainfall & $-930 ’ 4.12^{\prime \prime}$ & -361 '22.08" \\
\hline & 39870000 & Flowrate & & \\
\hline
\end{tabular}

Source: National Water Agency. 
Naval Research Laboratory (NRL) (Skamarock et al. 2005).

The WRF was set up with three integration domains: domain D1, with $81 \times 81$ points in the xy directions, a 25$\mathrm{km}$ grid spacing, and coverage of all of northeastern Brazil; domain D2, with $91 \times 91$ points in the xy directions and a horizontal grid spacing of $5 \mathrm{~km}$; and domain D3, with $151 \times 151$ points in the xy directions and a horizontal grid spacing of $1 \mathrm{~km}$.

To find the best configuration for the simulation, the nine microphysics and convection parametric schemes listed in Table 2 were evaluated. The results simulated with the WRF in domains D2 and D3 in two sub-basins, Atalaia (sub-basin SB12) and Viçosa (sub-basin SB9), and their upstream contribution areas were evaluated. No significant differences were observed between the results in domains D2 and D3; therefore, to reduce the computational effort, domain D2 was selected.

With the combinations of the microphysics and convection schemes, a matrix with nine elements was created (Table 3). The schemes referring to the surface boundary layer, soil surface layer, planetary boundary layer and atmospheric radiation were specified.

The WRF model was executed using the configuration listed in Table 4. The simulation spanned the $120 \mathrm{~h}$ from July 27, 2011, at 00Z, to July 31, 2011, at 00Z.

\subsection{NRCS-CN hydrological model}

Estimation surface runoff from rainfall data is of major importance in hydrological engineering and watershed management. Among the various methods available, the NRCS-CN methodology is widely accepted and popular (Verma et al., 2017). For the hydrological modelling using NRCS-CN, HEC-HMS software was used. The

Table 2 - Parametric schemes evaluated in the calibration of the WRF model.

\begin{tabular}{lc}
\hline Scheme & Notation \\
\hline Kessler (1969) - microphysics & MPK \\
Lin et al. (1983) - microphysics & MPL \\
Thompson et al. (2004) - microphysics & MPT \\
Kain and Fritsch (1993) - convection & KF \\
Betts and Miller (1986) and Janjić (1994) - convection & BMJ \\
Grell and Dévényi (2002) - convection & G3D \\
\hline
\end{tabular}

Table 3 - Possible combinations of the three microphysics schemes and three convection schemes in the WRF model.

\begin{tabular}{lccc}
\hline & KF & BMJ & G3D \\
MPK & MPK-KF & MPK-BMJ & MPK-G3D \\
MPL & MPL-KF & MPL-BMJ & MPL-G3D \\
MPT & MPT-KF & MPT-BMJ & MPT-G3D \\
\hline
\end{tabular}

Table 4 - Configuration of the WRF model using the parametric schemes.

\begin{tabular}{|c|c|c|}
\hline Configuration & Scheme & Reference \\
\hline Microphysics & Purdue Lin & Lin et al., 1983 \\
\hline Cumulus & Grell 3D & $\begin{array}{l}\text { Grell and Dévényi, } \\
2002\end{array}$ \\
\hline $\begin{array}{l}\text { Surface boundary } \\
\text { layer }\end{array}$ & MM5 Similarity & Beljaars, 1995 \\
\hline Soil surface layer & $\begin{array}{l}\text { Unified Noah Land Surface } \\
\text { Model }\end{array}$ & Tewari et al., 2004 \\
\hline $\begin{array}{l}\text { Planetary boundary } \\
\text { layer }\end{array}$ & $\begin{array}{l}\text { Asymmetric Convection } \\
\text { Model }\end{array}$ & Pleim, 2007 \\
\hline \multirow[t]{2}{*}{$\begin{array}{l}\text { Atmospheric radia- } \\
\text { tion }\end{array}$} & Goddard Shortwave & $\begin{array}{l}\text { Chou and Max, } \\
1994\end{array}$ \\
\hline & RRTMG Longwave & Iacono et al., 2008 \\
\hline
\end{tabular}

HMS allows the simulation of many hydrological processes in a hydrographic basin. The loss function was used to estimate the fraction of rainfall that converts to direct surface runoff. The transformation function used data from a hyetograph and made it possible to obtain the hydrograph at a control point in the basin. The HMS provided an automatic calibration tool to estimate the parameters of the hydrological model. The HMS is widely used in association with other HEC software to study floods in urban centers, flood frequency and flood losses (Singh and Woolhiser, 2002). In addition, the HMS is a multi-model program that allows the user to develop the most appropriate model for the analyzed system

For the loss function, the curve number (CN; NRCS, 1986) was applied. The method uses the $\mathrm{CN}$ coefficient, which depends on the use and type of soil. The exceeding rainfall was estimated using Eq. (1):

$$
P e=\left[\begin{array}{ll}
\frac{\left(P-I_{a}\right)^{2}}{P-I_{a}+S} & \text { if }\left(P-I_{a}\right)>0 \\
0 & \text { elsewhere }
\end{array}\right]
$$

where $P e$ is the effective rainfall of the event $(\mathrm{mm}), \mathrm{P}$ is the total rainfall of the event (mm), Ia corresponds to the initial losses (mm), and $S$ is the potential maximum retention of rainfall $(\mathrm{mm})$.

The value of $I a$ was estimated using Eq. (2):

$$
I a=0.2 S(2)
$$

Combining Eqs. (1)-(2) yields Eq. (3):

$$
P e=\left[\begin{array}{ll}
\frac{(P-0.2 S)^{2}}{P+0.8 S} & \text { if }(P-0.2 S)>0 \\
0 & \text { elsewhere }
\end{array}\right]
$$

The value of $S$ can be calculated as a function of the $C N$ using Eq. (4): 


$$
S=\frac{25400}{C N}-245
$$

The $C N$ ranges from 0 to 100 and varies as a function of the soil group and use, the occupation and the initial moisture condition. The $C N$ values were tabulated by the NRCS (NRCS). The estimated $C N$ can be refined by performing the automatic calibration available in the HMS model, which provides 14 objective functions for the calibration.

For converting the exceeding rainfall to a flowrate, the NRCS unit hydrograph method was used (Soil Conservation Service, 1972). It is one of the most widely used models in practice, due to its simplicity and ease of application (Milde et al., 2002).

\subsection{Analysis of model performance}

The performance of the model was assessed in the WRF configuration phase, in the WRF/HMS coupling and in flood forecasting. In the configuration and coupling phases, the following metrics were used: the bias (Eq. (5)), the root-mean-square error (RMSE; Eq. (6)) and the correlation coefficient $r$ (Eq. (7)). These three equations are as follows:

$$
\text { Bias }=\frac{1}{N} \sum_{i=1}^{N}\left(M_{i}-O_{i}\right)
$$

where $M_{i}$ is the $i$-th value obtained from the modeling (rainfall or flowrate), $O_{i}$ is the value observed at the surface (rainfall or flowrate), and $N$ is the number of data analyzed.

$$
R M S E=\sqrt{\left(\sum_{i=1}^{N}\left(M_{i}-O_{i}\right)^{2}\right) / N}
$$

where $M_{i}$ is the $i$-th value estimated by the model, $O_{i}$ is the value observed at the surface, and $N$ is the number of data analyzed.

$$
r=\frac{\operatorname{Cov}\left(O_{I}, M_{I}\right)}{S_{M_{i}} \cdot S_{O_{i}}}
$$

where $r$ is the linear correlation coefficient between $O_{i}$ and $M_{i}$; and $S_{M_{i}}$ and $S_{O_{i}}$ are the standard deviations of $M_{i}$ and $O_{i}$, respectively.

For the evaluation of the predictive ability, the NashSutcliffe (NS) coefficient, the Heidke skill score (HSS), the hit rate $(H)$ and the false alarm rate $(F A R)$ were used.

The NS values for the WRF model and for the coupled models were calculated using Eq. (8):

$$
N S=1-\frac{\sum_{i=0}^{n}\left(O_{i}-M_{i}\right)^{2}}{\sum_{i=0}^{n}\left(O_{i}-\bar{O}\right)^{2}}
$$

where $O_{i}$ is the observed value, $P_{i}$ is the simulated value, and $\bar{O}$ is the mean observed value; all variables may be for the rainfall or flowrate.

For rainfall, the HSS, estimated using Eq. (9), was applied by assuming two conditions: rainfall and no rainfall.

$$
H S S=\frac{2(x w-y z)}{[(x+z) \cdot(z+w)+(x+y) \cdot(y+w)]}
$$

where $x$ indicates that the model predicted rainfall and that rainfall occurred, $y$ indicates that the model predicted rainfall but that rainfall did not occur, $z$ indicates that the model did not predict rainfall but that rainfall occurred, and $w$ indicates that the model did not predict rainfall and that rainfall did not occur. Eq. (10):

The value of $H$ (dimensionless) was estimated using

$$
H=\frac{x+w}{n} .100
$$

where $n$ indicates the number of observations ( $x$ and $w$ were defined earlier).

The value of FAR was estimated using Eq. (11):

$$
F A R=\frac{y}{x+y}
$$

( $y$ and $x$ were defined earlier).

For the flood discharges, for alert purposes, the HSS was applied to three conditions: low flowrate or a normal condition, average flowrate or a watch condition, and a high flowrate or a warning condition. The HSS was calculated using Eq. (12):

$$
H S S=\frac{\frac{1}{N} \sum_{i=1}^{k} N\left(F_{i} O_{i}\right)-\frac{1}{N^{2}} \sum_{i=1}^{k} N\left(F_{i}\right) N\left(O_{i}\right)}{1-\frac{1}{N^{2}} \sum_{i=1}^{k} N\left(F_{i}\right) N\left(O_{i}\right)}
$$

where $n\left(F_{i}, O_{j}\right)$ is the number of forecasts in category $i$ that corresponded to observations in category $j, N\left(F_{i}\right)$ is the number of forecasts in category $I, N\left(O_{j}\right)$ is the number of observations in category $j$, and $N$ is the total number of forecasts. Table 5 presents the categories used to determine the HSS.

The $H S S$ values can range from -1 to 1 , where the value of 1 indicates a perfect forecast; zero indicates no predictive ability or a forecast equivalent to a reference forecast, i.e., a fortuitous coincidence; and -1 indicates performance inferior to a random forecast. 
Table 5 - HSS multi-category contingency table.

\begin{tabular}{|c|c|c|c|c|c|c|}
\hline \multirow[b]{2}{*}{ Predicted category } & \multicolumn{6}{|c|}{ Observed category } \\
\hline & $\mathrm{i} / j$ & Class 1 & Class 2 & $\ldots$ & Class k & Total \\
\hline & Class 1 & $\mathrm{n}\left(F_{1}, O_{1}\right)$ & $\mathrm{n}\left(F_{1}, O_{2}\right)$ & $\ldots$ & $\mathrm{n}\left(F_{1}, O_{k}\right)$ & $\mathrm{N}\left(F_{1}\right)$ \\
\hline & Class 2 & $\mathrm{n}\left(F_{2}, O_{1}\right)$ & $\mathrm{n}\left(F_{2}, O_{2}\right)$ & $\ldots$ & $\mathrm{n}\left(F_{2}, O_{k}\right)$ & $\mathrm{N}\left(F_{2}\right)$ \\
\hline & $\cdots$ & $\cdots$ & $\cdots$ & $\cdots$ & $\cdots$ & $\cdots$ \\
\hline & Class k & $\mathrm{n}\left(F_{k}, O_{1}\right)$ & $\mathrm{n}\left(F_{k}, O_{2}\right)$ & $\ldots$ & $\mathrm{n}\left(F_{k}, O_{k}\right)$ & $\mathrm{N}\left(F_{K}\right)$ \\
\hline & Total & $\mathrm{N}\left(O_{1}\right)$ & $\mathrm{N}\left(\mathrm{O}_{2}\right)$ & $\ldots$ & $\mathrm{N}\left(O_{K}\right)$ & $\mathrm{N}$ \\
\hline
\end{tabular}

\section{Results and Discussion}

\subsection{Atmospheric modeling}

\subsubsection{Calibration of the parametric configuration}

Table 6 presents the results of the nine combinations corresponding to Atalaia station. At this station, a negative bias prevails in the predictions by the WRF model, given that eight of the nine combinations yielded negative values. Combination MPK-KF yielded the lowest bias $(-0.01 \mathrm{~mm} / \mathrm{h})$. The second-lowest biases were those produced by combinations MPT-KF $(-0.07 \mathrm{~mm} / \mathrm{h})$ and MPL$\mathrm{KF}(0.07 \mathrm{~mm} / \mathrm{h})$. Combination $\mathrm{MPT}+\mathrm{KF}$ produced the lowest RMSE $(1.55 \mathrm{~mm} / \mathrm{h})$ and the highest $\mathrm{r}(0.68 \mathrm{~mm} / \mathrm{h})$. The correlation obtained in the analysis $(0.68 \mathrm{~mm} / \mathrm{h})$ was acceptable and was rated as strong based on the classification of Callegari-Jacques (2003). Thus, combination MPTKF performed best among the nine combinations: it performed best based on two indicators and second best based on the third indicator.

At Viçosa station, the WRF model captured the rainfall events well, although it underestimated the rainfall intensities there much more than it did at Atalaia station. The area scale factor used for the mean rainfall could be responsible for the lower quality of this forecast. The Viçosa area is much smaller than the Atalaia area. Table 7 shows that all the biases are negative, and the lowest value was $-0.42 \mathrm{~mm} / \mathrm{h}$.

Table 6 - Statistics for the simulations of the nine combinations evaluated using the WRF-ARW model, Atalaia station.

\begin{tabular}{lccr}
\hline Combination & $r$ & Bias & $R M S E$ \\
\hline MPK-KF & 0.55 & -0.01 & 1.82 \\
MPK-BMJ & 0.31 & -0.84 & 2.17 \\
MPK-G3D & 0.53 & -0.55 & 1.87 \\
MPL-KF & 0.63 & 0.07 & 1.66 \\
MPL-BMJ & 0.44 & -0.81 & 2.08 \\
MPL-G3D & 0.46 & -0.27 & 2.03 \\
MPT-KF & 0.68 & -0.07 & 1.55 \\
MPT-BMJ & 0.38 & -0.82 & 2.12 \\
MPT-G3D & 0.61 & -0.28 & 1.69 \\
\hline
\end{tabular}

Table 7 - Statistics of the simulation of the nine combinations evaluated in the WRF-ARW model, Viçosa station.

\begin{tabular}{lccc}
\hline Combination & $r$ & Bias & $R M S E$ \\
\hline MPK-KF & 0.42 & -0.97 & 2.05 \\
MPK-BMJ & 0.36 & -0.93 & 2.04 \\
MPK-G3D & 0.29 & -0.61 & 2.80 \\
MPL-KF & 0.46 & -1.02 & 2.08 \\
MPL-BMJ & 0.42 & -0.95 & 2.03 \\
MPL-G3D & 0.42 & -0.50 & 2.19 \\
MPT-KF & 0.21 & -0.99 & 2.14 \\
MPT-BMJ & 0.20 & -0.95 & 2.14 \\
MPT-G3D & 0.40 & -0.42 & 1.89 \\
\hline
\end{tabular}

$\mathrm{H}$ values exceeding $50 \%$ were obtained, except with combination MPT-KF, which yielded values of $44.54 \%$ and $42.86 \%$ for the Atalaia and Viçosa stations, respectively. The analysis revealed that the best $\mathrm{H}$ was produced by combination MPL-G3D: approximately $80 \%$.

For FAR values, the worst result was produced by combination MPT-KF, which yielded values of $55.46 \%$ and $53.21 \%$ for Atalaia and Viçosa stations, respectively. The best result was produced by combination MPK-BMJ, which yielded FARs of $21.43 \%$ and $13.95 \%$ for Atalaia and Viçosa stations, respectively.

Eight of the nine combinations yielded positive HSSs, indicating performance better than a random forecast. The highest HSS values, 0.5817 for Atalaia station and 0.5319 for Viçosa station, corresponded to combination MPL-G3D. The worst result was obtained with combination MPT-KF, which yielded values of 0 (zero) and -0.0836 , indicating that this combination is inadequate for rainfall forecasting in this region.

Based on these results, combination MPT-KF performed poorly. In contrast, the adjustments represented by combinations MPT-G3D and MPL-G3D provided the best rainfall simulations in the Paraíba do Meio River basin. Combination MPL-G3D was selected for use in the WRF model, given that it provided the best overall results. 


\subsubsection{Validation - application of the selected configuration}

For the validation of the WRF model, simulations spanning a 192-h time period were performed, i.e., $72 \mathrm{~h}$ longer than that of the configuration (calibration). Table 8 presents the results of the statistical analysis.

The RMSE obtained from the validation was within acceptable limits despite the high value corresponding to Atalaia station. HSS values of 0.37 and 0.61 were obtained for Viçosa and Atalaia stations, respectively (Table 8).

\subsection{Hydrological modelling}

The NRCS-CN hydrological model was calibrated using, as input, a time series of rainfalls with 120 records from the period of July 1 to 5,2013 . The basin was subdivided into 14 sub-basins (Fig. 2). Two flowrate stations were used in the calibration: the DCP of the city of Viçosa, located in sub-basin SB9, and the DCP of Atalaia (subbasin SB12).

\subsubsection{Calibration of the hydrological model}

For the calibration, manual and automatic searches for the best NRCS-CN parameters were performed. The manual method consisted of varying the parameters until

Table 8 - Statistical evaluation of the validation of the WRF model.

\begin{tabular}{lcccc}
\hline Station & $r$ & Bias $(\mathrm{mm} / \mathrm{h})$ & $R M S E(\mathrm{~mm} / \mathrm{h})$ & $H S S$ \\
\hline Atalaia & 0.32 & 0.07 & 10.45 & 0.61 \\
Viçosa & 0.15 & -0.09 & 2.92 & 0.37 \\
\hline
\end{tabular}

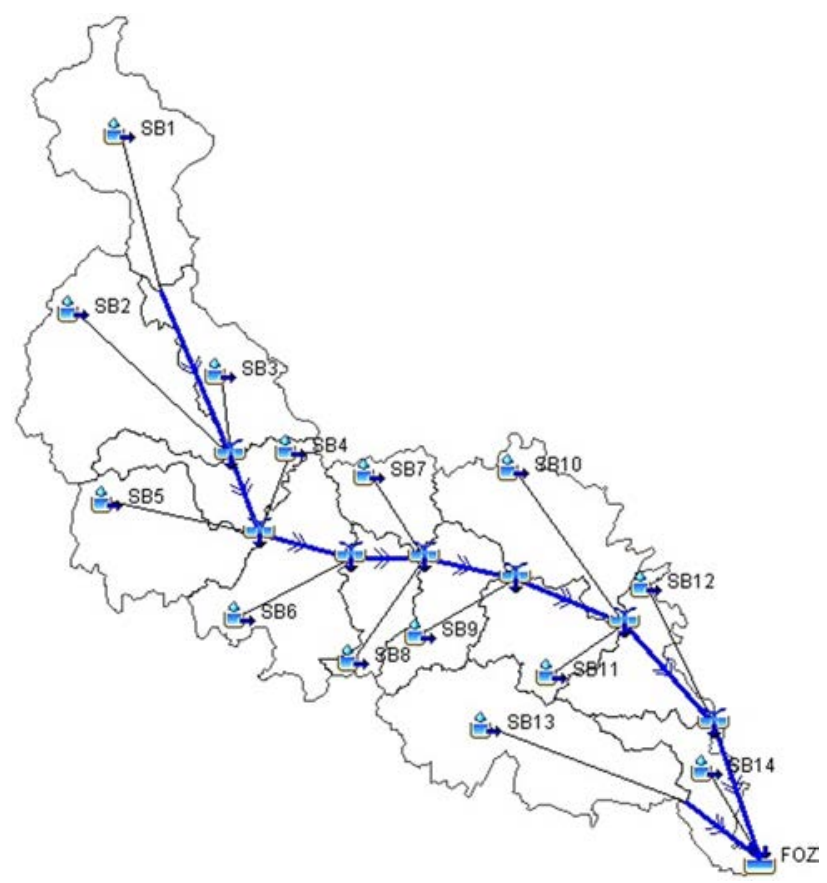

Figura 2 - Division of the Paraíba do Meio basin into sub-basins for simulation in the HEC/HMS. an optimal response was produced based on the judgment of the analyst. Due to its simplicity, this method is widely applied. During each trial, the adjustment of the maximum flowrates, the shape of the calculated hydrograph, the adjustment of the flood peaks and the calculated volume were analyzed. The CNs and response times (RTs) were thus calibrated.

The automatic calibration consisted of using the search tool available in the HEC-HMS. The parameters of the NRCS-CN hydrological model were adjusted to minimize the percent error peak objective function available in the HMS.

The results of the calibration are presented in Table 9. The adjustment provided simulated flowrates very close to the observed values. Based on the calibration, the predictive ability of the model was rated as adequate and good according to the classification developed by Motovilov et al. (1999). The mean NS coefficient of 0.822 between two points of analysis was obtained; a higher value was obtained for sub-basin SB12 (0.836). The relation between the simulated and observed series indicated a very strong correlation, with a mean coefficient of 0.921 and a median amplitude between the simulated and observed values of 0.57 , according to the RMSE. The model tended to underestimate the observed flowrate in the calibration phase; however, the flood peaks were satisfactorily simulated.

The hydrographs in Fig. 3 allow for a comparison between the observed and simulated series. Good fits of the flood peaks can be observed.

In addition, in the calibration phase, one of the most important aspects of a simulation of the flowrate for an alert system is the prediction of the hydrographs and the sizes of the peaks. Therefore, an adjustment that yielded better results in terms of these two properties was sought.

Meenu et al. (2013) calibrated the HEC-HMS in an evaluation of the impacts of climate changes in the hydrographic basin of the Tunga-Bhadra River in India. The results were statistically compatible with those obtained in this study. The consistency tests yielded satisfactory predictive ability, with an NS coefficient of 0.48 and $\mathrm{r}$ equal to 0.85 . According to Oleyiblo and Li (2010), despite the simple structure of the HEC-HMS, when calibrated, the

Table 9 - Statistical criteria evaluated in the calibration of the $H M S$ parameters with respect to observed rainfall in sub-basins SB9 and SB12.

\begin{tabular}{lcc}
\hline Statistical criterion & $\begin{array}{c}\text { Sub-basin SB9 } \\
\text { Calibrated }\end{array}$ & $\begin{array}{c}\text { Sub-basin SB12 } \\
\text { Calibrated }\end{array}$ \\
\hline$N S$ & 0.809 & 0.836 \\
$R$ & 0.905 & 0.938 \\
$R M S E$ & 0.073 & 1.067 \\
Bias & -0.184 & -5.837 \\
\hline
\end{tabular}



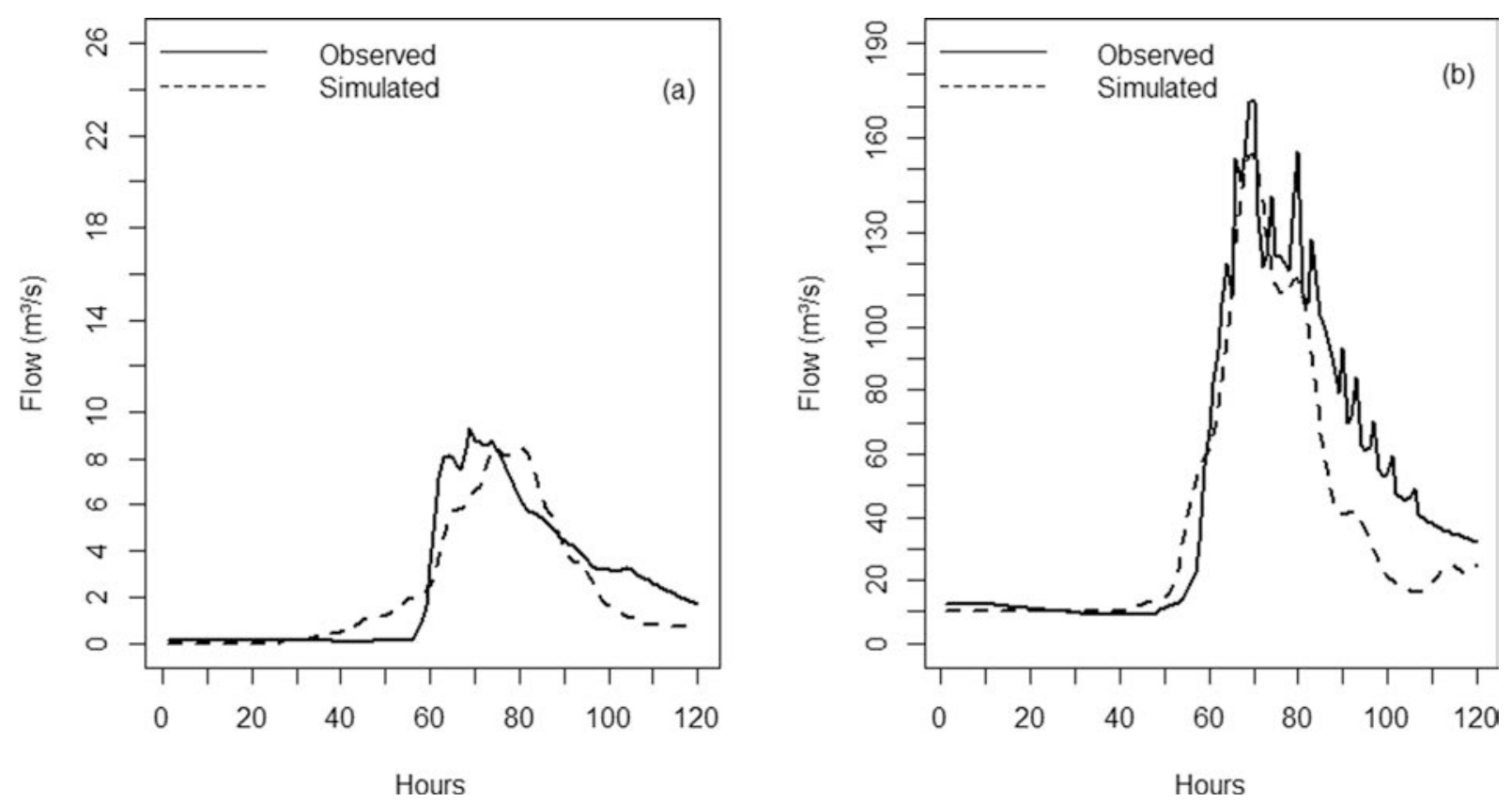

Figura 3 - Observed and simulated flowrates (observed rainfall) in the NRCS/HMS calibration phase, with the contribution of rainfall throughout the basin and with analysis point at the DCPs of sub-basins SB9 (a) and SB12 (b). The rainfall event spanned from July 1 to 5, 2013.

software becomes a powerful flood forecasting tool. Roy et al. (2013), in a forecasting study performed in eastern India, obtained an NS coefficient of 0.72 .

\subsubsection{Validation of the hydrological model}

The validation consisted of a model simulation using the parameters following their adjustment during another series of observed flowrates and rainfall amounts. The selected period spanned 192 hours from July 9 to 16 , 2013. The results are presented in Table 10.

The calibrations for sub-basins SB12 and SB9 yielded NS coefficients of 0.809 and 0.591 , respectively. Both values are satisfactory, particularly the value for SB12. The $r$ values were 0.945 and 0.908 for SB12 and SB09, respectively, indicating good correlations.

The flowrate peaks were simulated well by the model (Fig. 4). Although the peak in sub-basin SB9 (Fig. 4a) was below the observed value, the predictive ability of the model is considered satisfactory (NS =

Table 10 - Evaluation of the hydrological model in the validation of the HMS parameters, sub-basins SB9 and SB12.

\begin{tabular}{lcc}
\hline Statistical criterion & $\begin{array}{c}\text { Sub-basin SB9 } \\
\text { Validated }\end{array}$ & $\begin{array}{c}\text { Sub-basin SB12 } \\
\text { Validated }\end{array}$ \\
\hline$N S$ & 0.591 & 0.809 \\
$r$ & 0.945 & 0.908 \\
$R M S E$ & 0.295 & 1.251 \\
Bias & -2.257 & -3.866 \\
\hline
\end{tabular}

0.591), based on the classification of Motovilov et al. (1999).

The model underestimated the flowrates, based on the bias. However, low discrepancy between the two series was observed, based on the RMSE. Thus, the validation demonstrates the acceptable calibration of the model. The timing and intensity of the flood peaks were identified satisfactorily.

Given the results of the validation, coupling of the WRF atmospheric model and the NRCS-CN hydrological model was performed to evaluate the technique as a tool for forecasting hydrologic events in the Paraíba do Meio River basin.

\subsection{Unidirectional coupling of the hydrological model with the WRF}

Following the calibration and validation, the model was used to simulate the flowrate of the Paraíba do Meio River, using the rainfall simulated by the WRF atmospheric model as forcing in the NRCS-CN hydrological model. The grid points generated by the WEF model were selected in the BRPM limits for use as hypothetical pluviometers. The goal of this coupling of the WRF with the NRCS-CN model was to predict the flowrate in the extremely short term. The period of the coupling spanned from July 1 to 5, 2013.

The criteria were used to evaluate the efficacy of the coupling. The results of the evaluation are presented in Table 11. The technique proved to be suitable based on the statistical results. The implication is that the coupling is adequate to satisfactory, based on the NS coefficient. The 


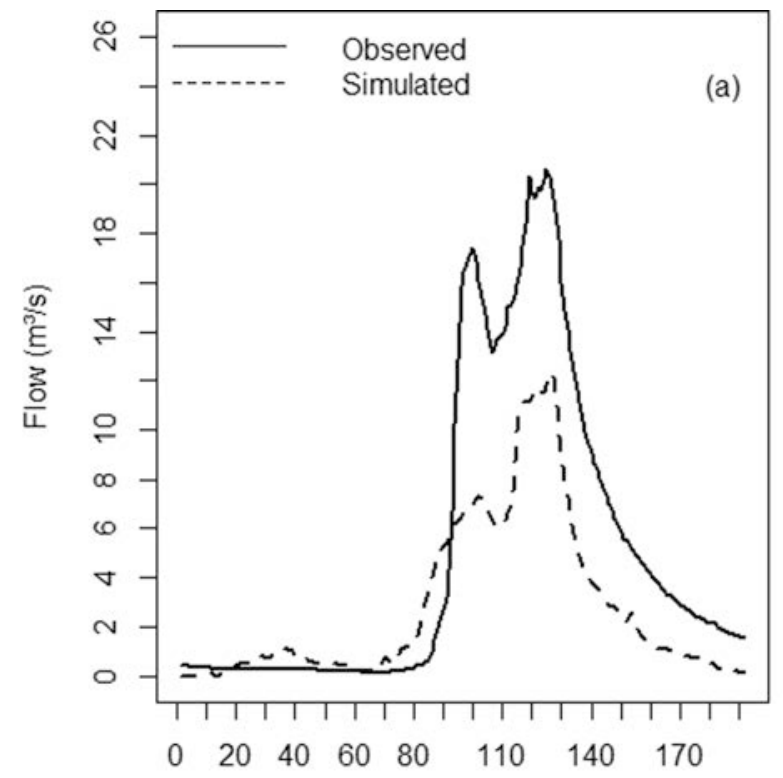

Hours

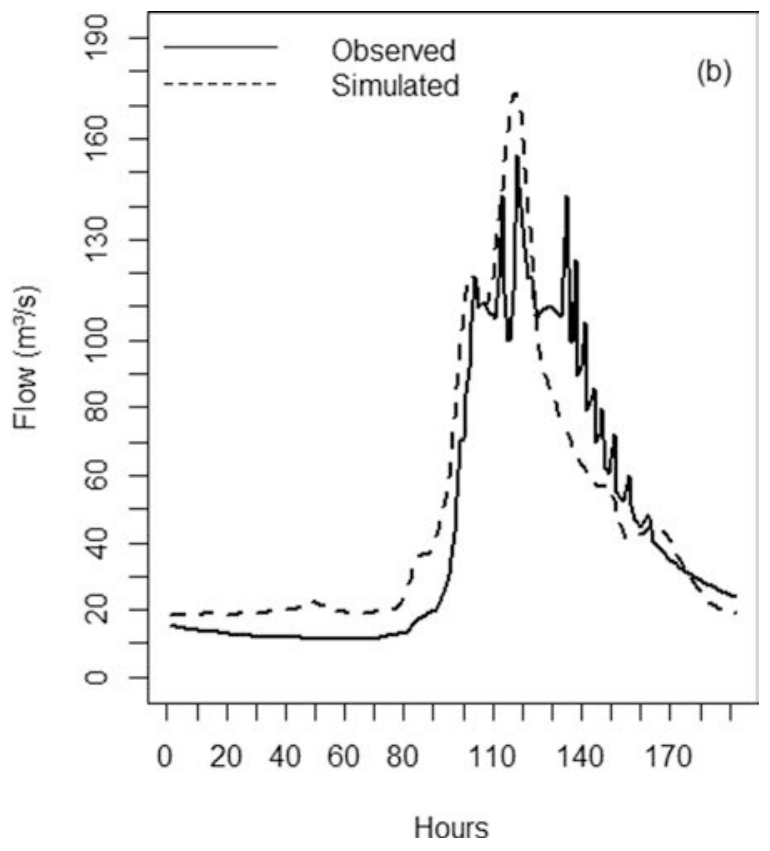

Figura 4 - Observed and simulated flowrates (observed rainfall) in the validation of the HMS, with the contribution of the rainfall throughout the basin and with analysis at the DCPs of sub-basins SB9 (a) and SB12 (b). The rainfall event spanned from July 9 to 16, 2013.

Table 11 - Statistical criteria evaluated in the coupling of the SCS/HMS with the WRF in sub-basins SB9 and SB12, period of July 1 to 5, 2013.

\begin{tabular}{|c|c|c|}
\hline \multirow[t]{2}{*}{ Statistical criterion } & Sub-basin SB9 & Sub-basin SB12 \\
\hline & Coupled & Coupled \\
\hline NS & 0.75 & 0.57 \\
\hline HSS & 0.25 & 0.73 \\
\hline$P A$ & $61 \%$ & $84 \%$ \\
\hline$r$ & 0.76 & 0.75 \\
\hline$R M S E\left(\mathrm{~m}^{3} / \mathrm{s}\right)$ & 0.11 & 2.49 \\
\hline $\operatorname{Bias}\left(\mathrm{m}^{3} / \mathrm{s}\right)$ & -0.24 & 13.15 \\
\hline
\end{tabular}

HSS, consistent with the Nash coefficient, indicates that the coupled system performed satisfactorily in sub-basin SB12. The system also yielded PA values of $84 \%$ and $61 \%$ in the flowrate simulations in sub-basins SB12 and SB9, respectively.

The correlations are 0.76 and 0.75 for sub-basins SB9 and SB12, respectively, indicating a low combined variation between the two series, which, consequently, led to a strong correlation.

Cabral et al. (2016) obtained an $\mathrm{r}$ of 0.48 for the coupling of the RAMS atmospheric model with the SMA hydrological model of the HEC-HMS when applied to the hydrographic basin of the Alto Jaguaribe River, in the state of Ceará.

In this study, the coupling yielded slight underestimation in sub-basin SB9. The relation between the observed series and the series simulated with the simulated rainfall is considered satisfactory, based on the low RMSE value. In sub-basin SB12, the coupling over- estimated the observed flowrates, based on much higher values of the bias and RMSE (Table 11). However, this sub-basin is large, and the bias of $13.15 \mathrm{~m} 3 / \mathrm{s}$ is not large in comparison to the flood flowrates, which exceed $100 \mathrm{~m}^{3} / \mathrm{s}$

Fig. 5 presents hydrographs of the observed and simulated flowrates. Although the predictions imperfectly simulated the peaks in the hydrographs, the technique was able to capture the flowrate variations in the basin during the period of analysis.

Based on the results, the method exhibits certain limitations, but it has demonstrated its potential as a flood forecasting tool starting with meteorological forecasts. However, further development is still necessary with regard to the configuration of the atmospheric model, given that the meteorological forecasts control the performance of the coupling.

According to Habets et al. (2004), despite all breakthroughs in atmospheric modelling, rainfall is still one of 

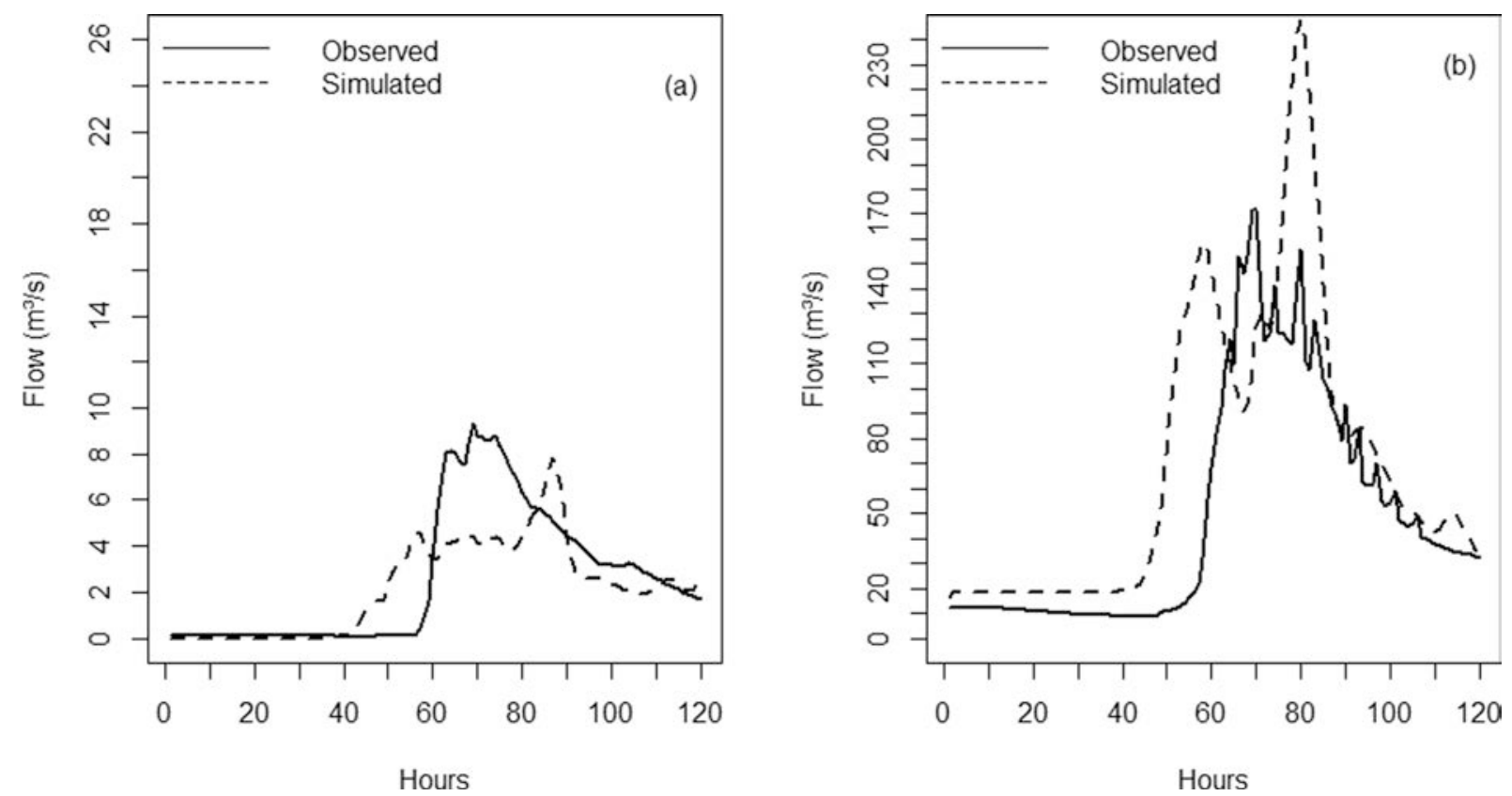

Figura 5 - Observed and simulated flowrates (simulated rainfall) from the coupling of the HMS (hydrological) and WRF (atmospheric) models, with contribution of rainfall throughout the basin and with analysis at the DCPs of sub-basins SB9 (a) and SB12 (b). The rainfall event spanned from July 1 to $5,2013$.

the most difficult variables to predict in that it displays large temporal and spatial variations. Nevertheless, despite the WRF model's great dependency on simulated rainfall values, the coupled model shows promise for the creation of a flood alert system.

\section{Conclusions}

This study of the configuration of the WRF atmospheric model indicates that the best parametric combination among the microphysics and convection schemes for extremely short-term rainfall forecasting in the Paraíba do Meio River basin are the schemes proposed by Purdue Lin (microphysics) associated with Grell 3D (convection). The model shows satisfactory predictive ability, based on our evaluation of statistical indicators.

The unidirectional coupling (WRF - NRCS-CN) proved to be suitable for extremely short-term flowrate forecasting and for decision-making regarding flood alerts. The coupling yielded correlation coefficients exceeding 0.75 . The predictive ability of the coupled system was good, based on NS coefficients of 0.749 and 0.572 for subbasins SB12 and SB9, respectively.

The HSS values corresponding to three flowrate categories $\left(\mathrm{Q} \leq 50,50<\mathrm{Q} \leq 100\right.$ and $\left.\mathrm{Q}>100 \mathrm{~m}^{3} / \mathrm{s}\right)$ were 0.73 for Atalaia station and 0.25 for Viçosa station. The most severe flooding hazard is in Atalaia, where the upstream discharge area is large $\left(2517.73 \mathrm{~km}^{2}\right)$.

In summary, the unidirectional coupling of the WRF, using the optimized configuration, with the NRCS-CN, using the optimized hydrological parameters, could serve well in developing flood alert systems.

\section{Acknowledgements}

The first author thanks to the Coordination of Improvement of Higher-Level Personnel (CAPES) by the Doctorship scholarship. The second author thanks National Council for Scientific Development $(\mathrm{CNPq})$ by the Grant 303658/2013-4.

\section{References}

ALMEIDA, V.A.; MARTON, E. Chuvas intensas em Santa Catarina: Análise Sinótica de um evento extremo e simulação numérica com o modelo atmosférico WRF. Anuário do Instituto de Geociências - UFRJ. v. 37, p. 169-179. 2014.

ALVES, J.M.B. Um vórtice ciclônico de altos níveis sobre o Nordeste do Brasil e Atlântico adjacente no verão de 1999. Rev. Bras. Meteor., v. 16, n. 1, p. 115-122, 2001.

ALVES, J.M.B.; CAMPOS, J.N.B.; SERVAIN, J. Reservoir management using coupled atmospheric and hydrological models: the Brazilian semi-arid case. Water Resour. Manage., v. 26, p. 1365-1385, 2012.

BELJAARS, A.C.M. The parametrization of surface fluxes in large-scale models under free convection. Q. J. R. Meteorolog. Soc., v. 121, p. 255-270, 1995.

BETTS, A.K.; MILLER, M.J. A new convective adjustment scheme. Part II: single column tests using GATE wave, 
BOMEX, ATEX and arctic air-mass data sets. Q. J. R. Meteorolog. Soc., v. 112, p. 693-709, 1986.

CABRAL, S.L.; CAMPOS, J.N.B.; SILVEIRA, C.S.; PEREIRA, J.M.R. O intervalo de tempo para uma máxima previsibilidade da precipitação sobre o semiárido Brasileiro. Rev. Bras. Meteor, v. 31, n. 2, p. 105-113, 2016.

CALLEGARI-JACQUES, S. M. Testes não paramétricos, In: Bioestatística, Porto Alegre: Artmed. P. 225, 2003.

CALVETTI, L.; PEREIRA FILHO, A.J.P. Ensemble Hydrometeorological Forecast Using WRF hourly QPF and TopModel for a Middle Watershed Advances in Meteorology, v. 2014, ID 484120, 2014.

CHEN, F.; KUSAKA, H.; BORNSTEIN, R.; CHIG, J.; GRIMMOND, C. 2011. The Integrated WRF/urban modelling system: development, evaluation, and applications to urban environment problems Int. J. Climatol, v. 31, p. 273-288, 2011.

CHOU, M.D.,;MAX J.S. An efficient thermal infrared radiation parameterization for use in general circulation models. NASA Tech. Memo: 104606, v. 3, p. 93, 1994.

GAN, M.A.; KOUSKY, V.E. Vórtices ciclônicos da alta troposfera no oceano Atlântico Sul. Rev. Bras. Meteor., v, 1, p. 19-28, 1986.

GRELL, G.A.; DÉVÉNYI, D. A generalized approach to parameterizing convection combining ensemble and data assimilation techniques. Geophys. Res. Lett., v. 29, n. 14, p. 1693-1696, 2002.

GIVATI, A.; LYNN, B.; LIU, Y.; RIMMER, A. Using the WRF model in na Operational Streamflow Forecast System in the Jordan River. Journal of Applied Meteorology and Climatology, v. 51, p. 285-299, 2012.

HABETS. F.; LEMOIGNE, P.; NOILHAN, J. On the utility of operational precipitation forecasts to served as input for streamflow forecasting. J. Hydrol., v. 293(1-4), p. 270288, 2004.

IACONO, M.J., DELAMERE, J.S., MLAWER, E.J., SHEPHARD, M.W., CLOUGH, S.A., COLLINS, W.D. Radiative forcing by long-lived greenhouse gases: calculations with the AER radiative transfer models. J. Geophys. Res. Atmos., v. 113, D13103, 2008.

JANJIĆ, Z.I. The step-mountain Eta coordinate model: Further developments of the convection closure schemes. Mon. Wea. Rev., v. 122, p. 927-945, 1994.

KAIN, J.S.; FRITSCH, J.M. The role of the convective "trigger function" in numerical forecasts of mesoscale convective systems. Meteor. Atmos. Phys., v. 49, p. 93-106, 1993.

KESSLER, E. On the distribution and continuity of water substance in atmospheric circulations, in: Proceedings of the Conference on the Distribution and Continuity of Water Substance in Atmospheric Circulations. American Meteorological Society, v.10, n. 32, p. 1-84, 1969.

KOUSKY, V.E. Frontal influences on northeast Brazil. Mon. Weather Rev., v. 107, p. 1140-1153, 1979.

LIN, Y.L.; RICHARD, D.F.; HAROLD, D.O. Bulk parameterization of the snow field in a cloud model. J. Climate Appl. Meteor., v. 22, p. 1065-1092, 1983.

LINARES-RODRIGUEZ, A.; LARA-FANEG, V. One-dayahead streamflow forecasting using artificial neural networks and a meteorological mesoscale model. J. Hydrol. Eng., v. 20, ID 05015001, 2015.
MEENU, R.; REHANA, S.; MUJUMDAR, P.P. Assessment of hydrologic impacts of climate change in Tunga-Bhadra river basin, India with HEC-HMS and SDSM. Hydrol. Processes, v. 27, p. 1572-1589, 2013.

MELLER, A., BUARQUE, D.C., PAIVA, R.C.D., DIAS, P.L.S., MOREIRA, D.S. Previsão de cheias por conjuntos difusos em curto prazo. Rev. Bras. Recur. Hídricos, v. 19, p. 3349, 2014.

MILDE, L.C.E.; MORAES, J.M.; MORTATTI, J.; FERRAZ, F.F.B.; GROPPO, J.D. Modelo espaço temporal HECHMS: avaliação na bacia de drenagem de Analândia. HECHMS space-time model evaluation in the Analândia watershed. Rev. Ciênc. Tecnol., v. 10, p. 61-69, 2002.

MOTOVILOV, Y.G.; GOTTSCHALK, L.; ENGELAND, K., BELOKUROV, A.E. Regional Model of Hydrological Cycle. Application to the NOPEX Region. Institute Report Series No. 105, Department of Geophysics, University of Oslo, Blindern, Oslo. 1999. Disponível em: https://folk.uio.no/kolbjoen/nygen/ECOMAG-REPORT. pdf. Acesso em 18 de junho de 2017.

OLEYIBLO, J.O.; LI, Z.J. Application of HEC-HMS for flood forecasting in Misai and Wan'an catchments in China. Water Sci. Eng., v. 3, p. 14-22, 2010.

PLEIM, J.E. A combined local and nonlocal closure model for the atmospheric boundary layer. Part I: model description and testing. J. Appl. Meteor. Climatol., v. 46, p. 13831395, 2007.

RAO, V.B.; LIMA, M.C.; FRANCHITO, S.H. Seasonal and interannual variations of rainfall over eastern northeast Brazil. J. Clim., v. 6, p. 1754-1763, 1993.

RATNA, B.R.; RATNAM, J.V.; BEHERA, S.K.; FREDOLIN, T.T.; YAMAGATA, T. Validation of the WRF regional climate model over the subregions of Southeast Asia: climatology and interannual variability Climate Research, v. 71, p. 263-280, 2017.

ROY, D., BEGAM, S., GHOSH, S., JANA, S. Calibration and validation of HEC-HMS model for a river basin in Eastern India. ARPN J. Eng. Appl. Sci., v. 8, p. 40-56, 2013.

SHAHID, M.A.; BOCCARDO, P.; USMAN, M.; ALBANANESE, A.; QAMAR, M.U. Predicting Peak Flows in Real Time through Event Based Hydrologic Modeling for a Trans-Boundary River Catchment. Water Resour. Manage, v. 31, n. 3, p. 793-810, 2017.

SHRESTHA, S.; KHATIWADA, M.; BABEL, M.S.; PARAJULI, K. Impact of Climate Change on River Flow and Hydropower Production in Kulekhani Hydropower Project of Nepal. Environ. Process., v. 1, p. 231-250, 2014.

SILVA, V.P.R.; PEREIRA, E.R.R.; ALMEIDA, R.S.R. Estudo da variabilidade anual e intra-anual da precipitação na região Nordeste do Brasil. Rev. Bras. Meteor., v. 27, p. 163-172, 2012.

SINGH, V.P.; WOOLHISER DA. Mathematical modeling of watershed hydrology. J. Hydrol. Eng., v. 7, p. 270-292, 2002.

SKAMAROCK, W.C.; KLEMP, J.B.; DUDHIA, J.; GILL, D.O.; BARKER, D.M.; WANG, W., POWERS, J.G. A description of the advanced research WRF version 2 National Center for Atmospheric Research Boulder Co., Mesoscale and Microscale Meteorology Division. NCAR Technical Note NCAR/TN-468+STR, 2005. Disponível em: http:// 
citeseerx.ist.psu.edu/viewdoc/download?

doi $=10.1 .1 .484 .3656 \&$ rep=rep1\&type=pdf. Acesso em 24 de Maio de 2017.

SOIL CONSERVATION SERVICE. National Engineering Handbook, Sec. 4, Hydrology, U. S. Department of Agriculture, Washington, DC. 762p. 1972.

SOIL CONSERVATION SERVICE. National Engineering Handbook, Sec. 4, Hydrology, Department of Agriculture, U. S. Governmemt Printing Office, Washington, DC. 146 p., 1986.

TEWARI, M.F.; CHEN, W, WANG J.; DUDHIA, M.A.; LEMONE K, MITCHELL ME, GAYNO G, WEGIEL J, CUENCA R.H. Implementation and verification of the unified NOAH land surface model in the WRF model, in: Proceedings of the $20^{\text {th }}$ Conference on Weather Analysis and Forecasting. $16^{\text {th }}$ Conference on Numerical Weather Prediction, Seattle, p. 11-15, 2004. Disponível em: http:// ams.confex.com/ams/84Annual/techprogram/paper_69061. $\mathrm{htm}$. Acesso em: 15 de Maio de 2017.

THOM, V.T.; KHOI, D.N.; LINH, D.Q. Using gridded rainfall products in simulating streamflow in a tropical catchment A case study of the Srepok River Catchment, Vietnam. J. Hydrol. Hydromech., v. 65, n. 1, p. 18-25, 2017.

THOMPSON, G.; RASMUSSEN, R.M.; MANNING, K. Explicit forecasts of winter precipitation using an improved bulk microphysics scheme. Part I: description and sensitivity analysis. Mon. Weather Rev., v. 132, n. 2, p. 519-542, 2004.

VERMA, S.; VERMA, R.K.; MISHRA, R.K.; SINGH, A.; JAYARAJ, G.K. A revisit of NRCS-CN inspired models coupled with RS and GIS for runoff estimation. Hydrologic Science Journal, v. 62, n. 12, p. 1891-1930, 2017.

VITORINO, M.I.; SILVA, M.E.S.; ALVES, J.M.B. Classificação de sistemas convectivos de mesoescala no setor norte do Nordeste Brasileiro. Rev. Bras. Meteor., v. 12, p. 21-32, 1997.

YAMAZAKI, Y.; RAO, V.B. Tropical cloudiness over the south Atlantic ocean. J. Meteor. Soc. Jpn., v. 55, p. 205-207, 1977.

YANG, J.; WANG, Z.H.; CHEN, F.; MIAO, S.; TEWARI, M.; VOOGT, J.A.; MYINT, S. Enhancing Hydrologic Modelling in the Coupled Weather Research and ForecastingUrban Modelling System. Boundary-Layer Meteorology, v. 155, n. 1, p. 87-109, 2015.

YU Z.; LAKHTAKIA, M. Simulating the river-basin response to atmospheric forcing by linking a mesoscale meteorological model and hydrologic model system. J. Hydrol., v. 218, p. 72-91, 1999.

License information: This is an open-access article distributed under the terms of the Creative Commons Attribution License (type CC-BY), which permits unrestricted use, distribution and reproduction in any medium, provided the original article is properly cited. 